\title{
PENGARUH PENGENDALIAN INTERNAL TERHADAP PENCEGAHAN FRAUD DI RUMAH SAKIT (Studi empiris pada Rumah Sakit swasta di Jabodetabek)
}

Dwi Zarlis

STIE Kusuma Negara

Email:dwizarlis@gmail.com

\begin{tabular}{|c|c|}
\hline ARTIKEL INFO & ABSTRACT \\
\hline $\begin{array}{l}\text { Keywords: fraud, control } \\
\text { environment, risk assessment, } \\
\text { activity control, information } \\
\text { and communication, } \\
\text { monitoring }\end{array}$ & $\begin{array}{l}\text { This study examined and proved the influence of internal control } \\
\text { against fraud in the hospital either simultaneously or partially. This study } \\
\text { used a questionnaire survey with } 86 \text { respondents taken from } 10 \text { hospitals in } \\
\text { Jabodetabek. Statistical tests using simultaneous significance test ( F test) } \\
\text { shows the influence of the independent variables with the same independent } \\
\text { variable. While significant partial test }(t \text { test) showed that the control } \\
\text { environment, risk assessment, control activities, information and } \\
\text { communication, and monitoring have tresults }>t \text { table at a significance level } \\
\text { of } 5 \% \text {, so partially significant effect have a value }<0.05 \text {. }\end{array}$ \\
\hline
\end{tabular}

\section{PENDAHULUAN}

Terciptanya tata kelola yang baik di rumah sakit dan di milikinya instrumen organisasi yang handal untuk menjadikan rumah sakit tetap survive sebagai pelayanan masyarakat merupakan tuntutan yang harus di penuhi. Hal ini sangat penting, karena rumah sakit merupakan pusat pertanggungjawaban yang bertanggung jawab terhadap pelayanan kesehatan masyarakat sehingga kesehatan yang di terima masyarakat dapat terjangkau dan berkualitas.

Pengelolaan rumah sakit yang baik tentunya akan memberikan acuan ataupun gambaran bagaimana rumah sakit terkelola secara transparan, adanya kemandirian, akuntabel, adanya pertanggungjwaban dan kewajaran sehingga kinerja keuangan pada rumah sakit dapat di capai sesuai dengan visi dan misi rumah sakit yang telah di tentukan sebelumnya. Namun demikian harapan tersebut belum sepenuhnya dapat di rasakan, hal ini di sebabkan karena belum memadainya organisasi untuk menciptakan pengelolaan yang baik dan belum terbangunnya komitmen yang tinggi dari para pengelola rumah sakit akibatnya muncul berbagai penyimpangan, penyelewengan, penyeludupan dan korupsi. Fenomena fraud menjadi sesuatu yang lumrah di rumah sakit

Tingginya intensitas praktik kecurangan, penipuan, dan penggelapan yang terjadi pada suatu institusi publik, dengan segala modusnya dari yang sederhana sampai yang sangat canggih dan rumit, seharusnya menyadarkan semua pihak untuk membangun komitmen terhadap penerapan tata kelola yang baik secara konsisten dan meluas pada semua lapisan karena adanya kesadaran dan komitmen akan mengakibatkan tidak tercapainya kinerja keuangan yang baik pada rumah sakit. Fraud (kecurangan) dapat terjadi di mana saja, dapat di lakukan oleh siapa saja dan berdampak kepada siapa saja yang dapat merugikan kepada semua pihak baik secara langsung maupun tidak langsung termasuk yang melakukan fraud tersebut

Kecurangan di dunia usaha dapat di lakukan oleh oknum karyawan baik di level manajemen bawah maupun pada tingkat manajemen atas. Kecurangan yang di lakukan oleh oknum tersebut merugikan stake holder (pemilik, rekanan, dokter, karyawan). Kecurangan yang terjadi di perusahaan akan mengakibatkan inefisiensi operasional perusahaan. Inefisiensi perusahaan akibat kecurangan adalah lemahnya daya saing perusahaan, penurunan pendapatan, kenaikan biaya, penurunan semangat kerja karyawan dan ancaman terhadap kelangsungan hidup perusahaan.

Pengendalian internal yang baik memungkinkan manajemen siap menghadapi perubahan ekonomi yang cepat, persaingan, pergeseran permintaan pelanggan dan fraud serta restrukturisasi untuk kemajuan yang akan datang (Ruslan, 2009). Jika pengendalian internal suatu perusahaan lemah maka kemungkinan terjadinya kesalahan dan fraud sangat besar. Sebaliknya, jika pengendalian internal kuat, maka kemungkinan terjadinya kesalahan dan fraud dapat di perkecil. Kalaupun 
kesalahan dan fraud masih terjadi, bisa di ketahui dengan cepat dan dapat segera di ambil tindakan tindakan perbaikan sedini mungkin.

Sebagai suatu entitas pelayanan kesehatan terhadap masyarakat, di perlukan suatu pemahaman mengenai pengendalian internal yang akan di terapkan oleh karyawan di rumah sakit, di mana jika hal ini di terapkan secara efektif maka dapat mencegah terjadinya fraud (kecurangan). Hal ini juga di jelaskan oleh Cuomo (2007), bahwa dengan di terapkannya pengendalian internal pada perusahaan profit ataupun non profit dapat melindungi asset perusahaan dari fraud dan tentunya membantu manajemen dalam melaksanakan segala aktivitasnya

Komponen pengendalian internal menurut COSO (Committee of Sponsoring Organizations of the Treadway Commission) terdiri dari 5 komponen yaitu lingkungan pengendalian, penaksiran resiko, aktivitas pengendalian, informasi dan komunikasi, dan pemantauan

\section{KAJIAN TEORI}

\section{Teori Keagenan ( Agency Theory)}

Teori keagenan ialah teori yang menjelaskan hubungan antara pemilik perusahaan dengan para manajer (agen) dalam menjalankan perusahaan. Dalam hal ini pemilik perusahaan memperkerjakan para agen untuk menjalankan perusahaan. Penelitian dalam teori agensi, mengadopsi dari teori ekonomi dan biasanya dilakukan dengan eksperimen dan bukti empiris. Teori agensi banyak digunakan untuk menganalisis hubungan antara dua pihak "prinsipal (majikan) dan agent (agen)".

\section{Fraud ( Kecurangan )}

Kecurangan adalah penipuan kriminal yang bermaksud untuk memberi manfaat keuangan kepada si penipu. Kriminal disini berarti setiap tindakan kesalahan serius yang dilakukan dengan maksud jahat. Dan dari tindakan jahat tersebut ia memperoleh manfaat dan merugikan korbannya secara financial.

\section{Fraud Triangle}

Fraud Triangle tersebut menunjukkan bahwa seseorang melakukan kecurangan didasarkan atas 3 faktor tersebut, yaitu:

1. Pressure (tekanan).

2. Opportunity (kesempatan).

3. Razionalization atau mencari pembenaran

\section{Pengendalian Internal}

Internal control terdiri dari 2 kata, yaitu internal dan control. Internal memiliki arti sebagai sesuatu yang berhubungan dengan suatu struktur organisasi.

Menurut COSO (The Committee of Sponsoring Organizations of the Treadway Commission), Pengendalian Internal adalah sebuah proses yang dihasilkan oleh dewan direktur, manajemen, dan personil lainnya, yang didesain untuk memberikan jaminan yang masuk akal yang memperhatikan tercapainya tujuan-tujuan efektif dan efisiensinya operasional, terpercayanya pelaporan keuangan, dan patuh pada hukum dan aturan yang berlaku

\section{Penelitian Terdahulu}

Tabel 1. Penelitian Terdahulu

\begin{tabular}{|c|c|c|c|c|}
\hline No. & Peneliti & Judul & Hasil & $\begin{array}{l}\text { Perbedaan } \\
\text { penelitian }\end{array}$ \\
\hline 1 & $\begin{array}{l}\text { Anindita } \\
\text { Primastuti }\end{array}$ & $\begin{array}{l}\text { Penilaian terhadap } \\
\text { pelaksanaan sistem } \\
\text { pengendalian intern } \\
\text { dalam pengelolaan } \\
\text { aset tetap pada } \\
\text { pemerintah kota } \\
\text { Depok }\end{array}$ & $\begin{array}{l}\text { Proses belanja asset } \\
\text { dan pengelolaan } \\
\text { asset pemerintah kota } \\
\text { Depok masih belum } \\
\text { sepenuhnya } \\
\text { mematuhi peraturan } \\
\text { perundangan }\end{array}$ & $\begin{array}{l}\text { Kecurangan yang } \\
\text { terjadi tidak pada } \\
\text { asset tetap }\end{array}$ \\
\hline 2 & Wilopo & Analisa faktor - & Pengendalian & Penelitian bukan \\
\hline
\end{tabular}




\begin{tabular}{|c|c|c|c|c|}
\hline No. & Peneliti & Judul & Hasil & $\begin{array}{c}\text { Perbedaan } \\
\text { penelitian }\end{array}$ \\
\hline & & $\begin{array}{l}\text { faktor yang } \\
\text { berpengaruh } \\
\text { terhadap } \\
\text { kecenderungan } \\
\text { kecurangan } \\
\text { akuntansi : Studi } \\
\text { pada perusahaan } \\
\text { publik dan BUMN } \\
\text { di Indonesia }\end{array}$ & $\begin{array}{l}\text { internal yang efektif, } \\
\text { tingkat ketaatan pada } \\
\text { aturan akuntansi, } \\
\text { keberadaan asimetri } \\
\text { informasi serta } \\
\text { moralitas manajemen } \\
\text { memberikan } \\
\text { pengaruh yang } \\
\text { signifikan terhadap } \\
\text { perilaku tidak etis } \\
\text { dan kecenderungan } \\
\text { kecurangan } \\
\text { akuntansi }\end{array}$ & $\begin{array}{l}\text { di lihat dari faktor } \\
\text { - faktor terjadinya } \\
\text { kecurangan. }\end{array}$ \\
\hline 3 & $\begin{array}{l}\text { Deni Retno } \\
\text { Tama }\end{array}$ & $\begin{array}{l}\text { Analisis kasus } \\
\text { kecurangan dan } \\
\text { proses investigasi, } \\
\text { Studi kasus pada } \\
\text { PT. X }\end{array}$ & $\begin{array}{l}\text { Kecurangan terjadi } \\
\text { karena lemahnya } \\
\text { pengendalian internal } \\
\text { dan perusahaan } \\
\text { belum mempunyai } \\
\text { metode pencegahan } \\
\text { dan penangkalan } \\
\text { yang memadai untuk } \\
\text { mencegah terjadinya } \\
\text { kecurangan }\end{array}$ & $\begin{array}{l}\text { Dengan adanya } \\
\text { upaya pencegahan } \\
\text { terhadap } \\
\text { kecurangan } \\
\text { dengan } \\
\text { meningkatkan } \\
\text { pengendalian } \\
\text { internal }\end{array}$ \\
\hline 4 & $\begin{array}{l}\text { Imam } \\
\text { Hidayat }\end{array}$ & $\begin{array}{l}\text { Perencanaan sistem } \\
\text { teknologi informasi } \\
\text { untuk mendeteksi } \\
\text { dan mencegah } \\
\text { fraud pada sistem } \\
\text { inventori }\end{array}$ & $\begin{array}{l}\text { Sistem dapat di } \\
\text { gunakan secara } \\
\text { periodik yang } \\
\text { berfungsi untuk } \\
\text { mendeteksi } \\
\text { kesalahan - } \\
\text { kesalahan yang } \\
\text { merupakan gejala } \\
\text { sebelum fraud yang } \\
\text { dapat menimbulkan } \\
\text { kerugian yang besar }\end{array}$ & $\begin{array}{l}\text { Pengendalian } \\
\text { internal juga di } \\
\text { implementasikan } \\
\text { pada prosedur } \\
\text { komputerisasi }\end{array}$ \\
\hline 5 & $\begin{array}{l}\text { Arie } \\
\text { Wibowo }\end{array}$ & $\begin{array}{l}\text { Analisa sistem } \\
\text { pengendalian intern } \\
\text { direktorat } \\
\text { pembinaan SMK }\end{array}$ & $\begin{array}{l}\text { Organisasi yang } \\
\text { memiliki } \\
\text { pengendalian internal } \\
\text { yang baik akan } \\
\text { memiliki kinerja } \\
\text { yang baik pula, } \\
\text { pengendalian internal } \\
\text { merupakan salah satu } \\
\text { kunci guna } \\
\text { menghantarkan } \\
\text { optimalisasi } \\
\text { pengelolaan sumber } \\
\text { daya dan } \\
\text { akuntabilitas } \\
\text { organisasi }\end{array}$ & $\begin{array}{l}\text { Belum } \\
\text { sepenuhnya } \\
\text { melakukan } \\
\text { penelitian untuk } \\
\text { sumber daya } \\
\text { manusia }\end{array}$ \\
\hline 6 & Ramdany & $\begin{array}{l}\text { Analisis faktor - } \\
\text { faktor yang }\end{array}$ & $\begin{array}{l}\text { Secara empiris } \\
\text { membuktikan adanya }\end{array}$ & $\begin{array}{l}\text { Variabel yang di } \\
\text { teliti hanya untuk }\end{array}$ \\
\hline
\end{tabular}




\begin{tabular}{|c|c|c|c|c|}
\hline No. & Peneliti & Judul & Hasil & $\begin{array}{c}\text { Perbedaan } \\
\text { penelitian }\end{array}$ \\
\hline & & $\begin{array}{l}\text { mempengaruhi } \\
\text { fraud }\end{array}$ & $\begin{array}{l}\text { pengaruh secara } \\
\text { signifikan internal } \\
\text { control dan religious } \\
\text { behavior terhadap } \\
\text { fraud kecuali } \\
\text { personal attitude } \\
\text { yang tidak } \\
\text { berpengaruh } \\
\text { terhadap fraud }\end{array}$ & $\begin{array}{l}\text { pengendalian } \\
\text { internal }\end{array}$ \\
\hline 7 & $\begin{array}{l}\text { Subagiono } \\
\text { Tjondro }\end{array}$ & $\begin{array}{l}\text { Pengaruh sistem } \\
\text { pengendalian intern } \\
\text { terhadap kepatuhan } \\
\text { wajib pajak hotel } \\
\text { dalam memenuhi } \\
\text { kewajibannya di } \\
\text { kota Semarang }\end{array}$ & $\begin{array}{l}\text { Sistem akuntansi dan } \\
\text { prosedur } \\
\text { pengendalian } \\
\text { terhadap kepatuhan } \\
\text { wajib pajak } \\
\text { berpengaruh secara } \\
\text { signifikan }\end{array}$ & $\begin{array}{l}\text { Variabel yang di } \\
\text { teliti bukan wajib } \\
\text { pajak dan } \\
\text { kepatuhan pajak }\end{array}$ \\
\hline 8 & $\begin{array}{l}\text { Mularia } \\
\text { Cornelia } \\
\text { Josephine } \\
\text { Sirait }\end{array}$ & $\begin{array}{l}\text { Pengaruh sistem } \\
\text { pengendalian } \\
\text { internal dan auditor } \\
\text { internal terhadap } \\
\text { fraud }\end{array}$ & $\begin{array}{l}\text { Ada pengaruh } \\
\text { signifikan system } \\
\text { pengendalian internal } \\
\text { dan auditor internal } \\
\text { baik secara parsial } \\
\text { maupun simultan } \\
\text { terhadap fraud }\end{array}$ & $\begin{array}{l}\text { Variabel yang di } \\
\text { teliti hanya untuk } \\
\text { pengendalian } \\
\text { internal }\end{array}$ \\
\hline 9 & $\begin{array}{l}\text { Prianto } \\
\text { Kusumo } \\
\text { Wibowo }\end{array}$ & $\begin{array}{l}\text { Analisis pengaruh } \\
\text { sistem } \\
\text { pengendalian } \\
\text { internal dan } \\
\text { kepatuhan auditor } \\
\text { terhadap kualitas } \\
\text { hasil laporan audit }\end{array}$ & $\begin{array}{l}\text { Sistem pengendalian } \\
\text { internal adan } \\
\text { kepatuhan auditor } \\
\text { secara simultan } \\
\text { berpengaruh } \\
\text { signifikan terhadap } \\
\text { kualitas hasil laporan } \\
\text { audit }\end{array}$ & $\begin{array}{l}\text { Yang di teliti } \\
\text { ialah fraud bukan } \\
\text { kualitas audit }\end{array}$ \\
\hline 10 & $\begin{array}{l}\text { Purna } \\
\text { Senjaya }\end{array}$ & $\begin{array}{l}\text { Peranan satuan } \\
\text { kerja audit internal } \\
\text { dan komite audit } \\
\text { independen dalam } \\
\text { pengawasan } \\
\text { penerapan } \\
\text { managemen resiko } \\
\text { dan pencegahan } \\
\text { fraud pada bank, } \\
\text { Studi kasus pada } \\
\text { bank XZY }\end{array}$ & $\begin{array}{l}\text { Bahwa peranan } \\
\text { satuan kerja audit } \\
\text { internal cukup efektif } \\
\text { guna mendukung } \\
\text { direksi dan komisaris } \\
\text { dalam mengawasi } \\
\text { penerapan } \\
\text { manajemen resiko } \\
\text { dan pencegahan } \\
\text { fraud }\end{array}$ & $\begin{array}{l}\text { Variabel yang di } \\
\text { teliti bukanlah } \\
\text { auditor internal } \\
\text { yang ada di } \\
\text { perusahaan }\end{array}$ \\
\hline
\end{tabular}

\section{Kerangka Pemikiran Teoritis}

Pengendalian internal di perlukan dalam rangka pengawasan terhadap jalannya operasional organisasi untuk mendapatkan jaminan bahwa rencana - rencana yang telah di tetapkan dapat berjalan dengan efektif. Pengendalian internal yang lemah dalam organisasi perusahaan akan membuka peluang untuk terjadinya fraud

Pengujian pengendalian internal menggunakan 5 elemen COSO yang terdiri dari lingkungan pengendalian, penaksiran resiko, aktivitas pengendalian, informasi dan komunikasi, dan pemantauan

Gambar 1. Rerangka pemikiran 


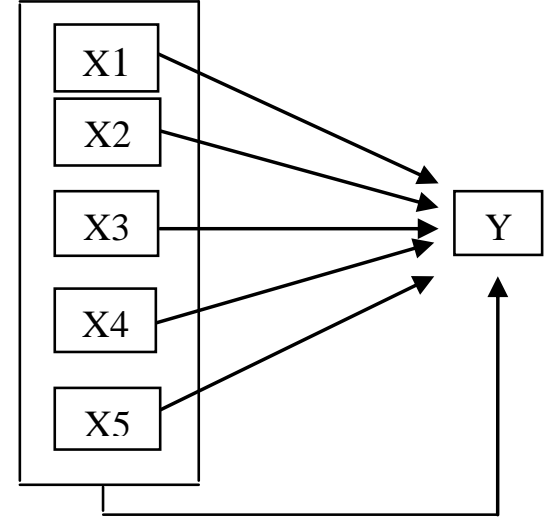

Di mana :

\section{$\mathrm{Y}$ : fraud}

$\mathrm{X} 1$ : lingkungan pengendalian

$\mathrm{X} 2$ : penaksiran resiko

X3: aktivitas pengendalian

X4: informasi dan komunikasi

X5: pemantauan

Dalam gambar di atas dapat di jelaskan bahwa lingkungan pengendalian, penaksiran resiko, aktivitas pengendalian, informasi dan komunikasi, dan pemantauan dapat berpengaruh untuk mencegah terjadinya fraud.

Lingkungan pengendalian merupakan dasar dari semua standar, lingkungan pengendalian di mana manajemen dan karyawan bersama - sama melaksanakan tanggung jawabnya dan saling mendukung dalam kelangsungan jalannya organisasi dengan membuat perencanaan, pelaksanaan dan pengawasan guna mencapai tujuan organisasi. Manajemen berperan penting dalam hal menciptakan etika organisasi dan memberikan etika yang baik, manajemen juga mendukung terhadap sistem informasi, akuntansi, pengawasan, audit dan evaluasi. Semua karyawan harus memiliki dan mempertahankan suatu tingkat kompetensi di mana karyawan dapat melaksanakan tugas yang di embannya. Dengan adanya lingkungan pengendalian yang baik dapat meminimalisir terjadinya kecurangan di dalam organisasi tersebut.

Penaksiran resiko di lakukan secara periodik dan manajemen harus menilai resiko berdasarkan prioritas. Metode identifikasi resiko dapat termasuk aktivitas merangking secara kualitatif dan kuantitatif, konferensi manajemen, perencanaan strategis, dan mempertimbangkan temuan - temuan audit. Dengan di lakukannya identifikasi faktor - faktor yang mempengaruhi resiko , menaksir resiko yang signifikan dan menentukan tindakan untuk mengelola resiko yang efektif akan meminimalisir terjadinya kecurangan.

Aktivitas pengendalian merupakan bagian dari perencanaan, implementasi, pelaporan dan pertanggungjawaban karyawan terhadap sumber daya dan pencapaian hasil yang efektif. Aktifitas pengendalian terdapat pada semua tingkatan mulai dari karyawan tingkat yang paling rendah sampai dengan tingkat yang paling tinggi, karena semua aktivitas seperti persetujuan, otorisasi, verifikasi, rekonsiliasi, laporan kinerja, pemeliharaan keamanan, pemeliharaan rekaman yang terkait yang menjadi bukti pelaksanaan kegiatan sesuai dengan dokumennya. Aktifitas pengendalian di buat dalam bentuk standar operasional prosedur yang harus di implementasikan oleh seluruh karyawan yang terkait. Dengan aktivitas pengendalian yang efektif dan konsisten, dapat meminimalisir terjadinya kecurangan.

Informasi dan komunikasi dalam suatu organisasi harus menjamin bahwa pelaksanaan pekerjaan di lakukan secara efektif, hal ini di lakukan dengan pertemuan, memorandum, kebijakan, prosedur manual dan laporan manajemen. Informasi harus di catat dan di komunikasikan kepada manajemen dan pihak lain dalam entitas yang membutuhkannya dan dalam sebuah bentuk dan pola waktu yang dapat di laksanakan dan pertanggungjawabkan. Komunikasi dan informasi harus relevan, andal dan dapat mencapai semua tujuan. Manajemen membuat sistem informasi untuk menjalankan semua transaksi yang akan di berikan kepada pengguna informasi tersebut. Dengan adanya informasi dan komunikasi yang efektif pelaksanaannya dapat mencegah terjadinya kecurangan.

Pemantauan yang di laksanakan secara terus menerus dan di evaluasi secara periodik dapat menjamin efektifitas pengendalian internal yang sedang berjalan. Informasi untuk penilaian dan perbaikan dapat berasal dari berbagai sumber meliputi studi atas struktur pengendalian internal, laporan internal audit, dan laporan penyimpangan. Dengan dilaksanakannya pemantauan dengan baik dapat mencegah terjadinya kecurangan. 


\section{METODE PENELITIAN}

\section{Jenis dan Sumber Data}

Penelitian ini merupakan studi empiris di beberapa rumah sakit swasta di jabodetabek. Penulis menggunakan metode statistik untuk mengolah data yang di peroleh dari hasil survei yang di kumpulkan dari hasil survey yang di kumpulkan melalui kuisioner dari responden. Hasil pengolahan data tersebut di olah dengan bantuan software statistik SPSS yang menghasilkan data berupa validitas, reliabilitas, regresi, korelasi dan determinasi.

\section{Populasi dan Sampel}

Data manajer dan front line manajer umum pada Rumah Sakit swasta di Jabodetabek ialah sebanyak 66 orang manajer dan 340 orang front line manajer Jumlah yang masuk dalam populasi penelitian ini berjumlah 406 orang.

Penelitian ini di ambil dengan tingkat kesalahan sebesar $10 \%$, maka di dapat dari hasil sampel sebagai berikut :

$$
\begin{aligned}
& \mathrm{n}=\mathrm{406} \\
& \mathrm{n}=\mathrm{1}+406 \times 10 \%^{2} \\
& \mathrm{n}=80.23 \\
& \mathrm{n}=80 \text { orang responden (di bulatkan) }
\end{aligned}
$$

\section{Metode Pengumpulan dan Pemilihan Data}

Pengumpulan data menggunakan metode penelitian lapangan dengan informasi di kumpulkan dari responden dengan menggunakan kuisioner. Dari jumlah sampel yang telah di tentukan di atas, peneliti langsung menyebarkan lembaran pertanyaan kepada manajer dan front line manajer sebanyak 100 orang di rumah sakit swasta di Jabodetabek.

Daftar pertanyaan akan di serahkan kepada responden dan hasil kuisioner yang telah di isi oleh responden akan di kumpulkan pada hari berikutnya untuk memberikan waktu kepada responden untuk mengisi daftar pertanyaan yang ada dalam daftar kuisioner.

Pertanyaan yang di ajukan bersifat tertutup dan terstruktur artinya responden hanya di berikan pilihan jawaban yang telah di tentukan oleh peneliti dan pertanyaan yang telah di urut sesuai dengan variabel yang di teliti.

\section{Metode Analisa Data}

\section{Rancangan Analisis}

Pengujian hipotesis di lakukan dengan menggunakan uji multiple regression untuk menganalisis hubungan antara variabel dependen (fraud) dengan beberapa variabel independen (lingkungan pengendalian, penaksiran resiko, aktivitas pengendalian, informasi dan komunikasi, pemantauan.

Penelitian ini menggunakan analisa regresi berganda. Analisis ini di gunakan untuk mengukur kekuatan dua variabel atau lebih dan juga menunjukkan arah hubungan antara variabel terikat dengan variabel independen, sebagai berikut :

$$
\mathrm{Y}=\alpha+\beta 1 \mathrm{X} 1+\beta 2 \mathrm{X} 2+\beta 3 \mathrm{X} 3+\beta 4 \mathrm{X} 4+\beta 5 \mathrm{X} 5+\varepsilon
$$

Di mana :

$$
\begin{array}{ll}
\mathrm{Y} & =\text { Fraud } \\
\alpha & =\text { Konstanta } \\
\beta 1-\beta 5 & =\text { Koefisien regresi } \\
\mathrm{X} 1 & =\text { Lingkungan Pengendalian } \\
\mathrm{X} 2 & =\text { Penaksiran Resiko } \\
\mathrm{X} 3 & =\text { Aktivitas Pengendalian } \\
\mathrm{X} 4 & =\text { Informasi dan Komunikasi } \\
\mathrm{X} 5 & =\text { Pemantauan } \\
\varepsilon & =\text { Error item }
\end{array}
$$




\section{HASIL PENELITIAN DAN PEMBAHASAN}

\section{Data Deskriptif Statistik}

Tabel 2.

\begin{tabular}{|c|c|c|c|c|c|}
\hline \multicolumn{6}{|c|}{ Descriptive Statistics } \\
\hline & $\mathrm{N}$ & Minimum & Maximum & Mean & $\begin{array}{c}\text { Std. } \\
\text { Deviation }\end{array}$ \\
\hline $\bar{Y}$ & 86 & 3.40 & 5.00 & 4.7186 & .40628 \\
\hline $\mathrm{X} 1$ & 86 & 2.80 & 5.00 & 4.0372 & .43873 \\
\hline X2 & 86 & 2.60 & 5.00 & 4.0302 & .46275 \\
\hline X3 & 86 & 3.00 & 5.00 & 4.1070 & .41580 \\
\hline X4 & 86 & 2.20 & 5.00 & 3.6535 & .59601 \\
\hline $\mathrm{X} 5$ & 86 & 2.60 & 4.80 & 3.6977 & .54427 \\
\hline $\begin{array}{l}\text { Valid N } \\
\text { (listwise) }\end{array}$ & 86 & & & & \\
\hline
\end{tabular}

\section{Hasil Uji Asumsi Klasik}

\section{Hasil Uji Normalitas}

Tabel 3. Hasil uji normalitas

\begin{tabular}{llr}
\multicolumn{2}{c}{ One-Sample Kolmogorov-Smirnov Test } & $\begin{array}{c}\text { Unstandardized } \\
\text { Residual }\end{array}$ \\
\hline $\mathrm{N}$ & Mean & 86 \\
Normal Parameters & & .0000000 \\
& Std. Deviation & .17839582 \\
Most Extreme Differences & Absolute & .133 \\
& Positive & .066 \\
Kolmogorov-Smirnov Z & Negative & -.133 \\
Asymp. Sig. (2-tailed) & & 1.231 \\
a. Test distribution is Normal. & .097 \\
\end{tabular}

Uji normalitas residual menggunakan uji kolmogorov-SmirnovZ di katakan normal jika nilai signifikansi > dari $0.05($ alpha $=5 \%)$. Dari tabel di atas dapat di simpulkan terdistribusi normal yaitu 0.097

\section{Hasil Uji Multikolinearitas}

Uji ini untuk mengetahui apakah terjadi korelasi antara variabel independen ( $\mathrm{x}$ ). Model yang baik seharusnya tidak terjadi korelasi. Berikut hasil olahan datanya :

Tabel 4. Hasil uji multikolinearitas

\section{Coefficients $^{\mathrm{a}}$}

\begin{tabular}{|c|c|c|c|c|c|c|c|c|}
\hline \multirow[b]{2}{*}{ Model } & & \multicolumn{2}{|c|}{$\begin{array}{l}\text { Unstandardized } \\
\text { Coefficients }\end{array}$} & \multirow{2}{*}{$\begin{array}{c}\text { Standardized } \\
\text { Coefficients } \\
\text { Beta } \\
\end{array}$} & \multirow[b]{2}{*}{$\mathrm{T}$} & \multirow[b]{2}{*}{ Sig. } & \multicolumn{2}{|c|}{ Collinearity Statistics } \\
\hline & & B & Std. Error & & & & Tolerance & VIF \\
\hline \multirow[t]{6}{*}{1} & (Constant) & 1.303 & .214 & & 6.080 & .000 & & \\
\hline & $\mathrm{X} 1$ & .157 & .068 & .170 & 2.312 & .023 & .448 & 2.231 \\
\hline & $\mathrm{x} 2$ & .160 & .075 & .182 & 2.125 & .037 & .328 & 3.053 \\
\hline & X3 & .199 & .083 & .204 & 2.390 & .019 & .331 & 3.017 \\
\hline & $X 4$ & .174 & .048 & .256 & 3.608 & .001 & .479 & 2.089 \\
\hline & X5 & .184 & .060 & .247 & 3.086 & .003 & .377 & 2.652 \\
\hline
\end{tabular}

a. Dependent Variable: $Y$ 
Uji multikolinearitas menggunakan VIF dan Tolerance. Apabila nilai VIF $<10$ dan TOL $>0,1$ maka di simpulkan tidak terdapat kasus multikolinearitas antar variabel independen.

\section{Hasil Uji Heterokedastisitas}

Di gunakan untuk mengetahui apakah terjadi heterokedastisitas dalam model regresi. Berikut hasil olahan datanya :

Tabel 5. Hasil uji Heterokedastisitas

\section{Coefficients $^{\mathrm{a}}$}

\begin{tabular}{|c|c|c|c|c|c|c|}
\hline \multirow[b]{2}{*}{ Model } & & \multicolumn{2}{|c|}{ Unstandardized Coefficients } & \multicolumn{2}{|l|}{$\begin{array}{c}\text { Standardized } \\
\text { Coefficients }\end{array}$} & \multirow[b]{2}{*}{ Sig. } \\
\hline & & $\mathrm{B}$ & Std. Error & Beta & $\mathrm{T}$ & \\
\hline \multirow[t]{6}{*}{1} & (Constant) & .344 & .117 & & 2.928 & .004 \\
\hline & $\mathrm{X} 1$ & -.008 & .037 & -.035 & -.215 & .830 \\
\hline & $\mathrm{X} 2$ & -.005 & .041 & -.024 & -.126 & .900 \\
\hline & X3 & -.034 & .046 & -.141 & -.740 & .462 \\
\hline & $\mathrm{X} 4$ & -.004 & .027 & -.026 & -.164 & .870 \\
\hline & X5 & .003 & .033 & .016 & .092 & .927 \\
\hline
\end{tabular}

a. Dependent Variable: ABS_RES

Uji heteroskedastisitas menggunakan uji Glejser, yaitu dengan meregresikan variabel independen terhadap absolut residual. Model regresi dikatakan bebas dari kasus heteroskedastisitas apabila dari masing-masing variabel independen diperoleh signifikansi lebih besar dari 0,05.

Dari tabel di atas semua variabel memiliki signifikasi > dari 0.05 , jadi dapat di simpulkan semua variabel independen bebas kasus heterokedastisitas.

\section{Hasil Uji Hipotesis}

Untuk mengukur pengaruh pengendalian internal terhadap pencegahan fraud di gunakan metode analisa regresi berganda. Hasil yang di peroleh ialah sebagai berikut :

\section{Hasil Uji Signifikan Simultan ( Uji F )}

Pengujian simultan untuk mengetahui signifikan atau tidaknya suatu pengaruh dari variabel bebas secara bersama - sama terhadap variabel terikat. Hasil data olahannya sebagai berikut :

Tabel 6. Hasil uji signifikan simultan

\begin{tabular}{llrrrrr}
\multicolumn{7}{c}{ ANOVA $^{\mathbf{b}}$} \\
Model & & Sum of Squares & Df & Mean Square & F & Sig. \\
\hline 1 & Regression & 11.325 & 5 & 2.265 & 66.984 & $.000^{\mathrm{a}}$ \\
& Residual & 2.705 & 80 & .034 & & \\
& Total & 14.030 & 85 & & &
\end{tabular}

a. Predictors: (Constant), X5, X1, X4, X3, X2

b. Dependent Variable: $Y$

Uji F digunakan untuk mengetahui apakah variabel independen secara bersama-sama berpengaruh terhadap variabel dependen. Dikatakan berpengaruh apabila nilai signifikansi kurang dari 0,05. Dari analisis regresi diperoleh nilai $F$ hitung sebesar 66,984 dan signifikansi 0,000 yang kurang dari 0,05 . Sehingga hipotesa menyatakan bahwa ada pengaruh lingkungan pengendalian, penaksiran resiko, aktivitas pengendalian, informasi dan komunikasi, dan pemantauan terhadap pencegahan fraud dan berdasarkan parameter statistik menyatakan bahwa $\mathrm{F}$ hitung sebesar 66,984 > F tabel 2,33 dan nilai signifikasi 0,000 kurang dari 0,05, maka kesimpulannya menerima $\mathrm{H} 1$ dan menolak $\mathrm{H} 0$ yang artinya lingkungan pengendalian, penaksiran resiko, aktivitas pengendalian, informasi dan komunikasi, dan pemantauan secara signifikan berpengaruh terhadap pencegahan fraud. 


\section{Hasil Uji Signifikan Parsial ( Uji t )}

Pengujian parsial di gunakan untuk mengetahui apakah adanya pengaruh dari variabel - variabel bebas ( independen ) secara parsial terhadap variabel yang tidak bebas ( dependen ). Hasil olahan datanya sebagai berikut :

Tabel 7. Hasil uji signifikan parsial

\section{Coefficients $^{\mathrm{a}}$}

\begin{tabular}{|c|c|c|c|c|c|c|}
\hline \multirow[b]{2}{*}{ Mode } & & \multicolumn{2}{|c|}{ Unstandardized Coefficients } & $\begin{array}{c}\text { Standardized } \\
\text { Coefficients }\end{array}$ & \multirow[b]{2}{*}{$\mathrm{T}$} & \multirow[b]{2}{*}{ Sig. } \\
\hline & & B & Std. Error & Beta & & \\
\hline \multirow[t]{6}{*}{1} & (Constant) & 1.303 & .214 & & 6.080 & .000 \\
\hline & $\mathrm{X} 1$ & .157 & .068 & .170 & 2.312 & .023 \\
\hline & $\mathrm{X} 2$ & .160 & .075 & .182 & 2.125 & .037 \\
\hline & X3 & .199 & .083 & .204 & 2.390 & .019 \\
\hline & $\mathrm{X} 4$ & .174 & .048 & .256 & 3.608 & .001 \\
\hline & X5 & .184 & .060 & .247 & 3.086 & .003 \\
\hline
\end{tabular}

a. Dependent Variable: $Y$

a. Hipotesa menyatakan bahwa ada pengaruh lingkungan pengendalian (X1) terhadap pencegahan fraud ( $\mathrm{Y}$ ) dan berdasarkan parameter statistik menyatakan bahwa $\mathrm{t}_{\text {hitung }} 2.312>$ $\mathrm{t}_{\text {tabel }} 1.988$ dan di peroleh nilai signifikansi $0,023<0.05$, maka kesimpulannya menerima $\mathrm{H} 2$ dan menolak H0, yang artinya lingkungan pengendalian (X1) secara signifikan berpengaruh terhadap pencegahan fraud $(\mathrm{Y})$

b. Hipotesa menyatakan bahwa ada pengaruh penaksiran resiko (X2) terhadap pencegahan fraud ( Y ) dan berdasarkan parameter statistik menyatakan bahwa $\mathrm{t}_{\text {hitung }} 2.125>\mathrm{t}_{\text {tabel }} 1.988$ dan di peroleh nilai signifikansi $0,037<0.05$, maka kesimpulannya menerima $\mathrm{H} 3$ dan menolak $\mathrm{H} 0$, yang artinya penaksiran resiko (X2) secara signifikan berpengaruh terhadap pencegahan fraud (Y)

c. Hipotesa menyatakan bahwa ada pengaruh aktivitas pengendalian (X3) terhadap pencegahan fraud ( Y ) dan berdasarkan parameter statistik menyatakan bahwa $t_{\text {hitung }} 2.390>t_{\text {tabel }} 1.988$ dan di peroleh nilai signifikansi $0,019<0.05$, maka kesimpulannya menerima $\mathrm{H} 4$ dan menolak H0, yang artinya aktivitas pengendalian (X3) secara signifikan berpengaruh terhadap pencegahan fraud (Y)

d. Hipotesa menyatakan bahwa ada pengaruh informasi dan komunikasi (X4) terhadap pencegahan fraud ( Y ) dan berdasarkan parameter statistik menyatakan bahwa $t_{\text {hitung }} 3.608>$ $\mathrm{t}_{\text {tabel }} 1.988$ dan di peroleh nilai signifikansi $0,001<0.05$, maka kesimpulannnya menerima H5 dan menolak H0, yang artinya informasi dan komunikasi (X4) secara signifikan berpengaruh terhadap pencegahan fraud (Y)

e. Hipotesa menyatakan bahwa ada pengaruh pemantauan (X5) terhadap fraud ( Y ) dan berdasarkan parameter statistik menyatakan bahwa $\mathrm{t}_{\text {hitung }} 3.086>\mathrm{t}_{\text {tabel }} 1.988$ dan di peroleh nilai signifikansi $0,003<0.05$, maka kesimpulannya menerima $\mathrm{H} 6$ dan menolak H0. Ini mempunyai makna pemantauan (X5) secara signifikan berpengaruh terhadap pencegahan fraud $(\mathrm{Y})$

Dapat di simpulkan bahwa secara bersama variabel independen (x) berpengaruh terhadap dependen (y) secara signifikan.

Model regresinya menjadi :

$$
Y=1.303+0,157 \times 1+0,160 \times 2+0,199 \times 3+0,174 \times 4+0,184 \times 5
$$

Dari persamaan model regresi tersebut di atas dapat di interpretasikan sebagai berikut :

a. Nilai konstanta sebesar 1,303 yang berarti jika variabel bebas bernilai nol maka besarnya nilai fraud sebesar 1,303 satuan

b. Koefisien regresi lingkungan pengendalian (x1) sebesar 0,157 yang berarti jika peningkatan lingkungan pengendalian (x1) sebesar 1 satuan akan menyebabkan meningkatnya pencegahan fraud (y) sebesar 0,157 satuan ( $15,7 \%)$ 
c. Koefisien regresi penaksiran resiko (x2) sebesar 0,160 yang berarti jika peningkatan penaksiran resiko (x2) sebesar 1 satuan akan menyebabkan meningkatnya pencegahan fraud (y) sebesar 0,160 satuan ( $16 \%$ )

d. Koefisien regresi aktivitas pengendalian (x3) sebesar 0,199 yang berarti jika peningkatan aktivitas pengendalian (x3) sebesar 1 satuan akan menyebabkan meningkatnya pencegahan fraud (y) sebesar 0,199 satuan ( 19,9\%)

e. Koefisien regresi informasi dan komunikasi (x4) sebesar 0,174 yang berarti jika peningkatan informasi dan komunikasi $(\mathrm{x} 4)$ sebesar 1 satuan akan menyebabkan meningkatnya pencegahan fraud (y) sebesar 0,174 satuan $(17,4 \%)$

f. Koefisien regresi pemantauan (x5) sebesar 0,184 yang berarti jika peningkatan pemantauan (x5) sebesar 1 satuan akan menyebabkan meningkatnya pencegahan fraud (y) sebesar 0,184 satuan $(18,4 \%)$

\section{Hasil Uji Koefisien Determinasi ( $\mathbf{R}^{2}$ )}

Tabel 8. Hasil uji koefisien determinasi

\begin{tabular}{lccrr}
\multicolumn{5}{c}{ Model Summary } \\
\hline Model & $\mathrm{R}$ & R Square & Adjusted R Square & $\begin{array}{c}\text { Std. Error of the } \\
\text { Estimate }\end{array}$ \\
\hline 1 & $.898^{\mathrm{a}}$ & .807 & .795 & .18389 \\
\hline a. Predictors: (Constant), X5, X1, X4, X3, X2 & &
\end{tabular}

Nilai koefisien determinasi atau adjusted $\mathrm{R}$ square $\left(\mathrm{R}^{2}\right)$ sebesar 0,795 menunjukkan bahwa kelima variabel independen memberikan pengaruh atau kontribusi terhadap variabel Y sebesar 79,5\% sedangkan sisanya sebesar 20,5\% dipengaruhi oleh variabel lain yang tidak diteliti dalam penelitian ini.

\section{Pembahasan Hasil Penelitian}

Pengaruh lingkungan pengendalian (X1), penaksiran resiko (X2), aktivitas pengendalian (X3), informasi dan komunikasi (X4), dan pemantauan (X5) terhadap pencegahan fraud (Y)

Hasil penelitian ini menunjukkan lingkungan pengendalian (x1), penaksiran resiko (x2), aktivitas pengendalian (x3), informasi dan komunikasi (x4), dan pemantauan (x5) secara simultan sudah teruji mempunyai pengaruh signifikan terhadap pencegahan fraud

\section{Pengaruh lingkungan pengendalian (X1) terhadap pencegahan fraud (Y)}

Dari hasil uji secara parsial ( uji t ) menunjukkan bahwa lingkungan pengendalian ( $\mathrm{x} 1$ ) mempunyai pengaruh yang cukup signifikan terhadap pencegahan fraud (y) Lingkungan pengendalian yang baik mempunyai pengaruh untuk mengurangi terjadinya fraud. Dalam uji hipotesa yang di atas, lingkungan pengendalian mendapatkan urutan kelima dengan nilai sebesar 15,5\% sebagai faktor yang berpengaruh dalam pencegahan kecurangan

Dalam lingkungan pengendalian terdapat integritas dan nilai etika dari karyawan dan manajemen, komitmen manajemen terhadap kompetensi, filosofi manajemen dan gaya operasional organisasi, struktur organisasi, pelimpahan wewenang dan pertanggungjawaban, sumber daya manusia, dan hubungan organisasi dengan pusat dan dewan legislatif. Lingkungan pengendalian yang efektif dapat mencegah terjadinya kecurangan.

\section{Pengaruh penaksiran resiko (X2) terhadap pencegahan fraud (Y)}

Dari hasil uji secara parsial ( uji t ) menunjukkan bahwa penaksiran resiko (x2) mempunyai pengaruh yang cukup signifikan terhadap pencegahan fraud (y). Penaksiran resiko yang benar mempunyai pengaruh untuk mengurangi terjadinya fraud. Dalam uji hipotesa yang di atas, penaksiran resiko mendapatkan urutan keempat dengan nilai sebesar $16 \%$ sebagai faktor yang berpengaruh dalam pencegahan kecurangan

Penaksiran resiko yang baik di lakukan secara periodik dan manajemen menilai resiko yang mengancam akuntabilitas publik dengan mengidentifikasi faktor yang mempengaruhi resiko, menaksir 
resiko yang berpengaruh secara signifikan dan menentukan tindakan yang di lakukan untuk mengelola resiko. Penaksiran resiko yang konsisten di lakukan dapat mencegah terjadinya kecurangan

\section{Pengaruh aktivitas pengendalian (X3) terhadap pencegahan fraud (Y)}

Dari hasil uji secara parsial ( uji t ) menunjukkan bahwa aktivitas pengendalian (x3) mempunyai pengaruh yang cukup signifikan terhadap pencegahan fraud (y). Aktivitas pengendalian yang baik mempunyai pengaruh untuk mengurangi terjadinya fraud. Dalam uji hipotesa yang di atas, aktivitas pengendalian mendapatkan urutan pertama dengan nilai sebesar $19,9 \%$ sebagai faktor yang berpengaruh dalam pencegahan kecurangan, berdasarkan uji hipotesa tersebut dapat di katakan aktivitas pengendalian merupakan faktor yang paling dominan untuk pencegahan kecurangan.

Aktivitas pengendalian berupa kebijakan dan prosedur yang harus efektif dan efisien dalam pelaksanaan pengendalian unit kerja. Aktivitas pengendalian terjadi pada semua tingkatan dan fungsi entitas. Aktivitas pengendalian yang baik dapat mencegah terjadinya kecurangan.

\section{Pengaruh informasi dan komunikasi (X4) terhadap pencegahan fraud (Y)}

Dari hasil uji secara parsial ( uji t ) menunjukkan bahwa informasi dan komunikasi (x4) mempunyai pengaruh yang cukup signifikan terhadap pencegahan fraud (y). Informasi dan komunikasi yang efektif mempunyai pengaruh untuk mengurangi terjadinya fraud. Dalam uji hipotesa yang di atas, Informasi dan komunikasi mendapatkan urutan ketiga dengan nilai sebesar 17,4\% sebagai faktor yang berpengaruh dalam pencegahan kecurangan.

Informasi yang sudah terintegrasi dengan relevan tentang organisasi dan sepak terjangnya harus di identifikasi dan di komunikasikan kepada pihak terkait untuk menjamin bahwa pelaksanaan pekerjaan di lakukan secara efektif. Informasi dan komunikasi yang efektif dapat mencegah terjadinya kecurangan.

\section{Pengaruh pemantauan (X5) terhadap pencegahan fraud (Y)}

Dari hasil uji secara parsial ( uji t ) menunjukkan bahwa pemantauan (x5) mempunyai pengaruh yang cukup signifikan terhadap pencegahan fraud (y). Pemantauan yang baik mempunyai pengaruh untuk mengurangi terjadinya fraud. Dalam uji hipotesa yang di atas, aktivitas pengendalian mendapatkan urutan kedua dengan nilai sebesar 18,4\% sebagai faktor yang berpengaruh dalam pencegahan kecurangan, berdasarkan uji hipotesa tersebut dapat di katakan pemantauan merupakan faktor yang paling dominan kedua untuk pencegahan kecurangan.

Pemantauan yang di laksanakan secara terus menerus dan di evaluasi secara periodik dapat mencegah terjadinya kecurangan dan juga dapat menemukan kekurangan untuk diperbaiki. Pemantauan yang efektif dapat mencegah terjadinya kecurangan.

\section{KESIMPULAN}

Berdasarkan hasil penelitian yang telah di uji, maka peneliti menyimpulkan sebagai berikut :

1. Terdapat pengaruh lingkungan pengendalian, penaksiran resiko, aktivitas pengendalian, informasi dan komunikasi, dan pemantauan secara simultan terhadap pencegahan fraud di rumah sakit.

2. Terdapat pengaruh lingkungan pengendalian yang signifikan terhadap pencegahan fraud di rumah sakit.

3. Terdapat pengaruh penaksiran resiko yang signifikan terhadap pencegahan fraud di rumah sakit

4. Terdapat pengaruh aktivitas pengendalian yang signifikan terhadap pencegahan fraud di rumah sakit

5. Terdapat pengaruh informasi dan komunikasi yang signifikan terhadap pencegahan fraud di rumah sakit

6. Terdapat pengaruh pemantauan yang signifikan terhadap pencegahan fraud di rumah

\section{DAFTAR PUSTAKA}

Ademdum. 1994. Internal Control Integrated Framework. NewYork: AICPA Publication 
Committee of Sponsoring Organizations (COSO) of Treadway Commission. 2004. Internal ControlIntegrated Framework. Jersey City

Copeland, Thomas E, and J. Fred Weston. 1992. Financial Theory a Coorporate

Policy.Third Edition. New York: The Dryden Press.

Cuomo, A. M. 2007. Internal Controls and Financial Accountability for Not--for-Profit Boards,

GAO, 1999. Standard for internal control in the federal Government.

Hall, J.2007. Sistem informasi Akuntansi

Ikatan Akuntan Indonesia, 2011. Standar Profesional Akuntan Publik, Penerbit Salemba Empat

Mulyadi, 2002, Auditing, Buku 1 dan 2, Edisi 6, Jakarta: Salemba Empat

Romney, Marshal B and steinbart, paul john. 2000 Accounting Information systems $8^{\text {th }}$ edition.

Root, J. 1998. Beyond COSO Intern Control to enhance corporate governance

Ruslan. 2009. Internal Control Berbasis COSO.

Tuanakotta, T. M. 2007. Akuntansi Forensik dan Audit Investigatif. Jakarta: Lembaga Penerbit Fakultas Ekonomi Universitas Indonesia (LPFE UI).

Warren, Reeve, dan Fess, dialihbahasakan oleh Aria Farahmita, Amugrahani, dan Taufik Hendrawan, 2006, Accounting- Pengantar Akuntansi, Buku 1, Edisi 21, Jakarta : Salemba Empat

Dungo Gihon Mariyama dan Taufikur Rahman, 2013. Pengendalian Internal atas BLU tetapi belum berjalan Efektif

Sarinah Joyce Margaret Rafael dan Sugiarto, 2013. Pengalaman dan Skeptisme Profesional berpengaruh signifikan terhadap kemampuan auditor internal dalam memdeteksi fraud

Wilopo, 2006. Analisis Faktor - Faktor yang Berpengaruh terhadap Kecurangan Akuntansi : Studi pada Perusahaan Publik dan Badan Usaha Milik Negara di Indonesia, Simposium Nasional Akuntansi ( SNA ) 9 di Padang 